Хромов А. В., a.khromov@arch.gov.ua, ORCID ID:0000-0002-9546-7089, к.i.н., голова, Державна архівна служба Украӥни, м. Київ

\title{
ПРАВОВЕ РЕГУЛЮВАННЯ ПОПОВНЕННЯ ДЕРЖАВНИХ АРХІВНИХ КОЛЕКЦІЙ ЧЕРЕЗ МЕРЕЖУ ІНТЕРНЕТ: ПРАКТИКА ТА ПРОБЛЕМИ ЗАСТОСУВАННЯ 1
}

\begin{abstract}
Анотація. Одним із ключових завдань роботи Державної архівної служби України та державних архівних установ є збереження та поповнення архівної спадшчини українського народу. У сучасному світі набули поширення інтернет-майданчики продажу антикварних предметів, зокрема історичних документів, які до недавнього часу майже не помічались державою як потенційне джерело поповнення архівних фондів державних архівів. Мета дослідження - надати характеристику та провести аналіз наявного механізму контролю за продажами архівних документів онлайн та поповнення державних архівних колекцій. Методами дослідження є: системний метод (для з 'ясування правових механізмів купівлі державою архівних документів в системі архівного законодавства України); загальнонауковий порівняльний та спеціальні порівняльно-правовий та порівняльно-історичний методи (для співставлення практики реалізацї цъього напряму діяльності держсавних архівів в Украӥні); формальноюридичний метод (для здійснення комплексної характеристики основних правових категорій архівного законодавства України); метод наукового тлумачення права (для обгрунтування змісту відповідних правових норм). Результат дослідження полягає в підготовці пропозииії щзодо внесення змін до окремих статей галузевого архівного закону та підзаконних актів, та/або врахування виявлених проблем під час підготовки нового архівного закону. Встановлено, шуо сучасне українське архівне законодавство лише декларує першочергове право держави на викуп документів Національного архівного фонду, однак на практиці иее не завжди відповідає дійсності. До недавнього часу Державна архівна служба Украйни та державні архівні установи майже не вживали адміністративних чи організаційних заходів щзодо забезпечення суспільного інтересу під час продажу історичних документів на інтернетаукиіонах. Внесено пропозичії щчодо вдосконалення профільного архівного законодавства та організаиії роботи державних архівів в цуьому напрямку.
\end{abstract}

Ключові слова: Національний архівний фонд, Державна архівна служба України, інтернет-аукціони, правове регулювання, експертиза цінності, державні архіви, архівні інформаційні ресурси.

Khromov A. $V_{\text {, }}$

a.khromov@arch.gov.ua, ORCID ID:0000-0002-9546-7089,

Candidate of Historical Sciences, Head,

State Archival Service of Ukraine, Kyiv

\section{LEGAL REGULATION OF REPLENISHMENT OF STATE ARCHIVAL COLLECTIONS THROUGH THE INTERNET: PRACTICE AND PROBLEMS OF PRACTICE AND PROBLEMS OF IMPLEMENTATION}

\begin{abstract}
One of the key tasks of the State Archival Service of Ukraine and state archival institutions is to preserve and replenish the archival heritage of the Ukrainian people. In the modern world, online platforms for the sale of antiques, including historical documents, have become widespread, which until recently were hardly noticed by the state as a potential source of replenishment of the archival funds of state archives. The purpose of the study is to characterize and analyze the existing mechanism of control over the sale of archival documents online and replenishment of state archival collections. The research methods are: system method (to clarify the legal mechanisms of the state purchase of archival documents in the system of archival legislation of
\end{abstract}

Автор заявляє про відсутність конфлікту інтересів.

Робота виконана в ініціативному порядку та не отримувала жодного фінансування. 
Ukraine); general scientific comparative and special comparative-legal and comparative-historical methods (for comparison of practice of realization of this direction of activity of state archives in Ukraine); formal legal method (for the implementation of a comprehensive description of the main legal categories of archival legislation of Ukraine); method of scientific interpretation of law (to substantiate the content of relevant legal norms). The result of the research is to prepare a proposal to amend certain articles of the sectoral archival law and bylaws, and / or take into account the identified problems during the preparation of a new archival law. It is established that the modern Ukrainian archival legislation only declares the primary right of the state to purchase documents of the National Archival Fund, but in practice this is not always true. Until recently, the State Archival Service of Ukraine and state archival institutions took almost no administrative or organizational measures to ensure the public interest in the sale of historical documents at online auctions. Proposals have been made to improve the relevant archival legislation and organize the work of state archives in this direction.

Key words: National Archival Fund, State Archival Service of Ukraine, online auctions, legal regulation, value examination, state archives, archival information resources.

JEL Classification: K-23

DOI: https://doi.org/10.36477/2616-7611-2021-09-04

Постановка проблеми. Українське архівне законодавство передбачає будь-яку форму власності на документи Національного архівного фонду (далі - НАФ), передбачених Конституцією та законами України, і що право власності на документи Національного архівного фонду охороняється законом. Так, Законом України «Про Національний архівний фонд та архівні установи» (Стаття 8), який був ухвалений ще в грудні 1993 року, встановлено, що «архівні документи, що нагромадилися за час діяльності державних органів, державних підприємств, установ та організацій, а також документи, що передані державним архівним установам іншими юридичними і фізичними особами без збереження за собою права власності, $є$ власністю держави» [1]. Пізніше законодавець закріпив право державної власності за архівними документами, які перебували на державному обліку та зберігались в державних архівах до 1991 року [2] та на архіви (носії архівної інформації) репресивних органів комуністичного тоталітарного режиму 19171991 років [3]. Водночас неврегульованим залишається питання поповнення фондів державних архівів історичними документами, які не віднесені до Національного архівного фонду України i до того не перебували на державному обліку.

Проблема збереження та поповнення (повернення) культурної спадщини $є$ одним із найактуальніших питань розробки наукових досліджень, міжнародного права та нормотворчості протягом багатьох десятиліть. Водночас варто відзначити, що основним вектором розробки даної проблеми в спеціалізованій архівознавчій, юридичній літературі та під час розробки правових актів було зроблено спроби вирішити проблеми реституції (репатріації) культурних, зокрема архівних, цінностей. Об'єктивно це можна пояснити історією становлення державотворення та системи архівних установ в Україні та політики метрополій до звезення у свої адміністративні центри архівів приєднаних земель.

Аналіз останніх досліджень і публікацій. Питання повернення українських архівів стоїть на порядку денному більше 100 років (з часів Української революції 1917-1921 років) [4], залишалось актуальним і в радянські часи [5], після здобуття незалежності Україною [6, с. 8], і принесло нові виклики з 2014 року після привласнення Росією українських архівів в тимчасово окупованому Криму та Севастополі та під час збройної агресії на Сході України. Різні аспекти цієї проблеми висвітлено в низці досліджень: істориківархівістів Т. Боряка [7], С. Кота [8; 9], І. Матяш [10; 11], Л. Левченко [12], Лозенко Л.І. [13], О. Нестулі [14], М. Палієнко [15], Г. Папакіна [16] та інших; в наукових роботах правників, зокрема роботи В. Акуленка $[17 ; 18]$. У загальноєвропейському дискурсі теж тривалий час гостро стоїть питання «common archival heritage» - належності та кооперації спільної архівної спадщини країн Свропи[19; 20].

Постановка завдання. Фактично недослідженим залишається питання поповнення системи державних архівів історичними документами, які залишились поза сховищами і стають об'єктом купівлі-продажу в антикварних магазинах та на тематичних інтернет-платформах, що становить актуальність даного дослідження та вимагає негайного вирішення. Зокрема, потребує вдоско- 
налення механізм викупу державою історичних документів та його правове врегулювання, що передбачає ряд законодавчих змін.

Виклад основного матеріалу дослідження. Чинне українське архівне законодавство загалом описало основні принципи формування Національного архівного фонду та перспективного поповнення сховищ державних архівних установ. Окремий розділ (Розділ II) Закону України «Про Національний архівний фонд та архівні установи», що є профільним для архівного законодавства законом [1], присвячений якраз питанням формування НАФ. Так, законодавець декларує, що «НАФ формується у порядку, встановленому цим Законом, 3 архівних документів державних органів, органів місцевого самоврядування, підприємств, установ та організацій усіх форм власності, а також архівних документів громадян і їх об'єднань», і що держава має вживати заходів «для поповнення НАФ документами культурної спадщини України, що знаходяться за кордоном, та документами іноземного походження, що стосуються історії України, у пріоритетному порядку фінансує їх виявлення, взяття на облік, передання, придбання або відтворення в копіях» [1].

Ключовою дією для віднесення чи вилучення документів до/з НАФ є експертиза цінності, яка проводиться за ініціативи власника або державною архівною установою за згодою власника. Спори щодо цих питань вирішуються в судовому порядку. Водночас «юридичні і фізичні особи, які мають архівні документи, від часу створення яких минуло понад 50 років, або які мають намір здійснити їх відчуження чи вивезення за межі України, зобов'язані повідомити про це одну 3 державних архівних установ з метою вирішення питання про проведення експертизи цінності цих документів. Без повідомлення державної архівної установи відчуження архівних документів, вивезення їх за межі України забороняються» [1].

У наступному розділі ІІІ Закону України «Про Національний архівний фонд та архівні установи», зокрема в статті 10, виписано процедуру передачі права власності на документи НАФ. Законодавець визначив, що документи НАФ, які належать державі, територіальним громадам, не можуть бути об'єктом приватизації, купівліпродажу, застави або інших угод, пов'язаних 3 передачею права власності, і надаються лише в тимчасове користування. Право власності на зазначені документи може бути передане лише згідно 3 міжнародними договорами, згода на обов'язковість яких надана Верховною Радою
України, і законами України. У разі продажу документа НАФ держава має переважне право на його купівлю за ціною, оголошеною для продажу. У разі відмови від здійснення цього права чи нездійснення його протягом місяця з дня одержання повідомлення власник або уповноважена ним особа мають право на продаж документа. Переважне право держави на купівлю документа, що перебуває у приватній власності, не застосовується, якщо його покупцем є діти, дружина або чоловік, батьки, рідні брати і сестри, дід та баба як з боку батька, так і з боку матері...» [1]. Фактично цими вимогами означено основні засади державної політики щодо поповнення НАФ.

Архівні документи на інтернет-аукціонах - проблемні питання щодо викупу державою. Більш ніж сторічна історія становлення системи державних архівів України мала безліч драматичних сторінок, які негативно впливали на збереженість архівної культурної спадщини. Війни, репресії, стихійні лиха, пожежі, перевезення та переміщення архівів, адміністративні та організаційні реформи, періоди соціального занепаду та зростання кримінальної активності мали вплив в тому числі і на втрати документів Національного архівного фонду. Підтвердженням тому $є$ періодична поява історичних документальних артефактів у вільному продажу в антикварних крамницях та, в останні декілька років, здебільшого на онлайн-аукціонах, тематичних інтернет-майданчиках.

До останнього часу державні архівні установи та Укрдержархів, як центральний орган виконавчої влади, який реалізує державну політику в архівній справі та діловодстві, обіймали малоактивну позицію в цьому питанні та не займались системним моніторингом онлайн-продажу архівних документів. Окремі перевірки ймовірної належності лотів до фондів державних архівів проводились лише у випадку широкого розголосу.

Протягом 2020-2021 роківситуація кардинально змінюється та Державна архівна служба України оперативно проводить перевірки походження історичних документів на інтернет-аукціонах та співпрацює з потенційними меценатами, які поповнюють фонди архівів викупленими справами [21].

Персональнийдосвідавторастаттіщодовикупу та дарування історичних документів в фонди державних архівів виявив такі варіанти потрапляння культурної спадщини на онлайн-аукціони:

1) справи [22] вибули 3 державного обліку та зберігання в радянські часи в рамках численних кампаній по цільовій експертизі фондів (зокрема 
так звані «макулатурні кампанії») та виділення на знищення «малозначимих справ»;

2) справи, які були викрадені з архівів в невідомий часовий проміжок та рахуються в архівному розшуку;

3) справи 3 приватних колекцій, які ніколи не перебували на державному зберіганні, але можуть поповнити НАФ.

Робота щодо переведення цих справ на державне зберігання виявила низку проблемних питань: повернення до обліку «знищених» справ, строки давності щодо фактів можливої крадіжки документів, відсутність прав держави на історичні документи до моменту надання їм статусу документів НАФ. Якщо перші два питання вирішуються організаційно - через вдосконалення облікової роботи та взаємодії з правоохоронними органами, то вдосконалення механізму викупу державою історичних документів потребує законодавчих змін.

Пропозиції щодо вдосконалення процедур поповнення фондів державних архівів. Чинний архівний закон, як зазначалось вище, декларує переважне право держави на викуп документа НАФ під час продажу власником [1]. Віднесення історичного документального артефакту до документів НАФ може бути здійснене на підставі експертизи цінності за ініціативи, при дозволі та за участі власника [1], Фактично державні архіви не мають можливості викупу історичних документів до отримання ними статусу документа НАФ внаслідок експертизи цінності [23], яка неможлива без доброї волі продавця, часто анонімного власника.

Вирішити цю проблему можна шляхом доповнення архівного закону новелою в частині дистанційної експертизи та введення поняття «потенційного документа НАФ».

Зокрема, вбачається доречним передбачити право центрального органу виконавчої влади, що реалізує державну політику у сфері архівної справи та діловодства, державних архівних установ здійснювати дистанційну експертизу цінності архівних документів, що потенційно можуть набути статусу документів НАФ, за їх описом або електронними копіями без згоди власника у разі виникнення загрози їх знищення, значного погіршення стану, виявлення власником наміру відчуження, продажу, у тому числі з аукціонів, та з метою реалізації переважного права держави на придбання документів, що в результаті експертизи цінності набудуть статусу документів НАФ.
Висновки і перспективи подальших досліджень у даному напрямі. Українське архівне законодавство загалом доволі детально описує шляхи формування Національного архівного фонду, водночас передбачає різні форми власності на документи НАФ. Практика правозастосування свідчить про декларативність норм щодо прав та можливості викупу та поповнення фондів державних архівних установ історичними документами, які зберігаються у приватних осіб.

Вітчизняна та західна історіографія більшою мірою концентрує свою увагу на проблемах реституції, обміну та спільного користування архівною спадщиною.

Аналіз діяльності спільної роботи Державної архівної служби України та меценатів протягом 2020-2021 років щодо поповнення фондів державних архівів історичними артефактами, які перебували у вільному продажу на інтернет-аукціонах, виявив низку проблемних адміністративноправових питань. Запропоновано шляхи їх вирішення через зміни до архівного законодавства.

\section{ЛІТЕРАТУРА:}

1. Про Національний архівний фонд та архівні установи : Закон України від 24.12.1993 p. № 3814-XII (в редакції від 16.10.2020). URL: https://zakon.rada.gov.ua/laws/show/3814-12.

2. Про внесення змін до Закону України «Про Національний архівний фонд та архівні установи» : Закон України від 05.07.2012 р. № 5068-VI. URL: https://zakon.rada.gov.ua/laws/show/5068-17.

3. Про доступ до архівів репресивних органів комуністичного тоталітарного режиму 1917-1991 років : Закон України від 09.04.2015 р. №316-VIII. URL: https://zakon.rada.gov.ua/laws/show/316-19.

4. Лупандін О.І. Питання реституції культурних цінностей в контексті українсько-російських мирних переговорів 1918 р. Проблеми вивчення історії Украӥнської револючї 1917-1921 років. Київ : Інститут історії України. 2020. Вип. 5. С. 287-314.

5. Повернення на Україну архівних матеріялів із Москви. Бюлетень Укриентрархіву. № 17(19). Харків. 25 листопада 1926 року. С. 6-8.

6. Попова Л.М., Хромов А.В. Проблема правової визначеностіунікальних документів Національного архівного фонду. Наше право: науково-практичний журнал. Харків : ХНУВС, 2021. № 15. С. 5-13.

7. Боряк Т.Г. Концепт «україніки» у практичній діяльності з розшуку та повернення архівної україніки з Росії (1917 - сер. 1930-х рр.). Спеціальні історичні дисципліни. Київ : Інститут історії України, 2011. № 18. С. 38-43. 
8. Кот С.I. 3 історії формування організаційних засад державної політики повернення та реституції культурних цінностей в незалежній Україні. Історія України: Маловідомі імена, подї, факти. 2010. C. 361-371.

9. Кот С.I. Проблеми повернення культурних цінностей в українсько-російських міждержавних відносинах (1991-2015 років). Украӥна ХХ століття: культура, ідеологія, політика. 2016. Вип. 21. С. 160-177.

10. Матяш І.Б. Архівна україніка в Канаді: історіографія, типологія, зміст. Київ : Гооробець, 2008. $150 \mathrm{c}$.

11. Матяш І.Б. Концепція створення та функціонування Національного реєстру «Архівна україніка». Студії з архівної справи та документознавства. Київ, 2007. Т. 15. С. 12-18.

12. Левченко Л.Л. Чорноморський військовоморський архів (1794-1934). Дослідження. Документи. Реєстр фондів: реконструкція. Миколаїв : Іліон, 2018.660 c.

13. Лозенко Л.І. Архівні втрати України: вивезене до Росії. Пам’ятки України. Київ, 1994. № 3-6. C. 87-91.

14. Нестуля О.О. Визвольні змагання українського народу і охорона пам'яток культури: 19171920 рр. Полтава, 1993. 90 с.

15. Паліснко М.Г. Архівні центри української еміграції (створення, функціонування, доля документальних колекцій). Київ : Темпора, 2008. 687 с.

16. Папакін Г.В. Переміщені архіви: спадщина поділеного світу (тези). Архіви України. 2004. № 3(254). С. 87-88.

17. Акуленко B.I. Міжнародне право охорони культурних цінностей та його імплементація у внутрішньому праві України. Київ : Юстініан, 2013. $616 \mathrm{c}$.

18. Акуленко B.I. Політико-правові проблеми повернення культурних цінностей між державами СНД. Праиі Центру пам'яткознавства. Ч. 1. 2009. Вип. 15. С. 5-17; Ч. 2. 2010. Вип. 17. С. 5-15.

19. Biernat A. Problems of the accessibility to common archival heritage - invitation to common archival heritage - invitation to cooperation. The common archival heritage of state and nations of Central and Eastern Europe. Warszawa, 1998. P. 29-32.

20. Kecskemeti C. Common European Archival Heritage. The common archival heritage of state and nations of Central and Eastern Europe. Warszawa, 1998. P. 17-18.

21. Метричну книгу повернули на зберігання до Державного архіву Чернігівської області / Офіційний сайт Державної архівної служби України.
URL : https:// https://archives.gov.ua/ua/метричнукнигу-повернули-на-зберіган/.

22. Державний архів Житомирської області. Ф. 119. Оп. 9. Спр. 914.

23. Про проведення експертизи цінності документів: Постанова кабінету Міністрів України від 08.08.2007 р. № 1004 (зі змінами в редакції від 04.11.2016 p.). URL : https://zakon.rada.gov.ua/laws/ show/1004-2007n.

\section{REFERENCES:}

1. Pro Natsionalnyi arkhivnyi fond ta arkhivni ustanovy: Zakon Ukrainy vid 24.12.1993 r. № 3814-XII (v redaktsii vid 16.10.2020). URL: https://zakon.rada.gov.ua/laws/show/3814-12 [stanom na 29.03.2021].

2. Pro vnesennia zmin do Zakonu Ukrainy «Pro Natsionalnyi arkhivnyi fond ta arkhivni ustanovy»: Zakon Ukrainy vid 05.07.2012 r. № 5068-VI. URL: https://zakon.rada.gov.ua/laws/show/5068-17 [stanom na 29.03.2021].

3. Prodostupdoarkhivivrepresyvnykhorhanivkomunistychnoho totalitarnoho rezhymu 1917-1991 rokiv: Zakon Ukrainy vid 09.04.2015 r. № 316-VIII. URL: https://zakon.rada.gov.ua/laws/show/316-19 [stanom na 29.03.2021].

4. Lupandin O.I. Pytannia restytutsii kulturnykh tsinnostei v konteksti ukrainsko-rosiiskykh myrnykh perehovoriv 1918 r. Problemy vyvchennia istorii Ukrainskoi revoliutsii 1917-1921 rokiv. Kyiv: Instytut istorii Ukrainy. 2020. Vyp.5. S.287-314.

5. Povernennia na Ukrainu arkhivnykh materiialiv iz Moskvy. Biuleten Ukrtsentrarkhivu. № 17 (19). Kharkiv. 25 lystopada 1926 roku. S.6-8.

6. Popova L.M., Khromov A.V. Problema pravovoi vyznachenosti unikalnykh dokumentiv Natsionalnoho arkhivnoho fondu. Nashe pravo: naukovo-praktychnyi zhurnal. Kharkiv: KhNUVS, 2021. № 15. S. 5-13.

7. Boriak T.H. Kontsept «ukrainiky» u praktychnii diialnosti $\mathrm{z}$ rozshuku ta povernennia arkhivnoi ukrainiky z Rosii (1917 - ser. 1930-kh rr.). Spetsialni istorychni dystsypliny. Kyiv: Instytut istorii Ukrainy, 2011. № 18. S.38-43.

8. Kot S.I. Z istorii formuvannia orhanizatsiinykh zasad derzhavnoi polityky povernennia ta restytutsii kulturnykh tsinnostei $\mathrm{v}$ nezalezhnii Ukraini. Istoriia Ukrainy: Malovidomi imena, podii, fakty. 2010. S. 361-371.

9. Kot S.I. Problemy povernennia kulturnykh tsinnostei $\mathrm{v}$ ukrainsko-rosiiskykh mizhderzhavnykh vidnosynakh (1991-2015 rokiv). Ukraina XX stolittia: kultura, ideolohiia, polityka. 2016. Vyp. 21. S. 160-177. 
10. Matiash I.B. Arkhivna ukrainika v Kanadi: istoriohrafiia, typolohiia, zmist. Kyiv: Hoorobets, 2008. $150 \mathrm{~s}$.

11. Matiash I.B. Kontseptsiia stvorennia ta funktsionuvannia Natsionalnoho reiestru «Arkhivna ukrainika». Studii z arkhivnoi spravy ta dokumentoznavstva. Kyiv, 2007. T.15. S.12-18.

12. LevchenkoL.L.Chornomorskyiviiskovo-morskyi arkhiv (1794-1934). Doslidzhennia. Dokumenty. Reiestr fondiv: rekonstruktsiia. Mykolaiv: Ilion, 2018. $660 \mathrm{~s}$.

13. Lozenko L.I. Arkhivni vtraty Ukrainy: vyvezene do Rosii. Pamiatky Ukrainy. Kyiv, 1994. № 3-6. S. 87-91.

14. Nestulia O.O. Vyzvolni zmahannia ukrainskoho narodu i okhorona pamiatok kultury: 1917-1920 rr. Poltava, 1993. $90 \mathrm{~s}$.

15. Paliienko M.H. Arkhivni tsentry ukrainskoi emihratsii (stvorennia, funktsionuvannia, dolia dokumentalnykh kolektsii). Kyiv: Tempora, 2008. $687 \mathrm{~s}$.

16. Papakin H.V. Peremishcheni arkhivy: spadshchyna podilenoho svitu (tezy). Arkhivy Ukrainy. 2004. № 3(254). S. 87-88.

17. Akulenko V.I. Mizhnarodne pravo okhorony kulturnykh tsinnostei ta yoho implementatsiia $u$ vnutrishnomu pravi Ukrainy. K.: Yustinian, 2013. 616 s.

18. Akulenko V.I. Polityko-pravovi problemy povernennia kulturnykh tsinnostei mizh derzhavamy
SND. Pratsi Tsentru pamiatkoznavstva. Ch. 1. 2009. Vyp. 15. S. 5-17; Ch. 2. 2010. Vyp. 17. S. 5-15.

19. Biernat A. Problems of the accessibility to common archival heritage - invitation to common archival heritage - invitation to cooperation. The common archival heritage of state and nations of Central and Eastern Europe. Warszawa, 1998. P. 29-32.

20. Kecskemeti C. Common European Archival Heritage. The common archival heritage of state and nations of Central and Eastern Europe. Warszawa, 1998. P. 17-18.

21. Metrychnu knyhu povernuly na zberihannia do Derzhavnoho arkhivu Chernihivskoi oblasti / Ofitsiinyi sait Derzhavnoi arkhivnoi sluzhby Ukrainy // Rezhym dostupu: https:// https://archives.gov.ua/ua/ metrychnu-knyhu-povernuly-na-zberihan/ [stanom na 06.04.2021].

22. Derzhavnyi arkhiv Zhytomyrskoi oblasti. F. 119. Op. 9. Spr. 914.

23. Pro provedennia ekspertyzy tsinnosti dokumentiv: Postanova kabinetu Ministriv Ukrainy vid 08.08.2007 r. № 1004 (zi zminamy v redaktsii vid 04.11.2016 r.). URL: https://zakon.rada.gov.ua/laws/ show/1004-2007n [stanom na 07.04.2021].

Стаття надійшла до редакиії 01.06.2021 